\title{
Identification of Crucial Risks Categories in Construction Projects in Tanzania
}

\author{
1. Eng. Philemon, Z. Msomba \\ Doctoral Student, \\ Department of Structural and Construction Engineering, \\ College of Engineering and Technology (COET), \\ University of Dar es salaam, Tanzania]
}

\author{
2. Dr. Matiko Samson \\ Lecturer, \\ Department of Structural and Construction Engineering, \\ College of Engineering and Technology (COET), \\ University of Dar es Salaam, Tanzania
}

\author{
3. Dr. Ramadhan, S. Mlinga \\ Lecturer, \\ Department of Structural and Construction Engineering, \\ College of Engineering and Technology (COET), \\ University of Dar es Salaam, Tanzania
}

\begin{abstract}
This paper presents the risks identified to significantly affect construction projects in Tanzania. Data was collected using questionnaire survey and review of project files implemented by three government entities. Based on a comprehensive assessment of the likelihood of occurrence and impacts on the project objectives, the survey identifies twenty four [24] risk factors significantly affecting construction project performance. The results demonstrate that inadequate project planning, inadequate project funding, inadequate pricing, fire, poor performance of contractor, poor contractor and supplier selection, inappropriate contract awards, inefficient delivery methods, inadequate survey data and design error and omissions have significant impact on schedule, budget and quality project objectives. It is recommended that clients, consultants and Government entities must work collaboratively from the feasibility phase of the project onwards to address potential risks in time. It is further recommended that contractors and subcontractors with varsity knowledge and experience in construction and management must be employed in early stages of the contract to make sound contributions towards safe, efficient and quality construction activities.
\end{abstract}

Keywords: Construction Projects, Risk Management, Risk Category, Project Life Cycle

\subsection{INTRODUCTION}

Risk is a multifaceted concept (Wang et al, 2004), which is defined as the probability of a damaging event occurring in the project, affecting its objectives (Yu, 2002; Baloi and Price, 2003) however, not always associated with negative results. Risk may also represent opportunities, but the fact that most of the risks usually have negative results has led individuals to only consider the negative side of risk (Hillson, 2011). Construction projects in Tanzania often experience delays, cost overruns and non-conformance to quality, leading to poor performance and dissatisfied parties (Msita and Mamiro, 2010). Consequently, projects are generally seen as unpredictable in terms of delivery on time, within budget and to the expected standards of quality (Zou et al, 2007). An understanding of the driving forces behind such problems is a priority if the performance of construction projects is to be improved. Indeed any project has to deal with issues that can affect its objectives. It is good practice to predict these issues so that the project team devise proactive counter-measures, and thus limit the possible adverse impacts. Risks have an adverse impact on construction projects performance in terms of cost, time and quality (Ahmed et al., 2007). According to RFB (2009) and PPRA (2011), in Tanzania the performance characteristics of projects indicates that the management of risks is poor, incomplete, and inconsistent throughout the construction industry, which signifies that the country has not focused on effective risk management.

Risk identification is the process of systematically and continuously identifying, categorizing, and assessing the initial significance of risks associated with a construction project (Al -Bahar and Crandall 1990). A risk cannot be managed unless it is first identified. The identification should be performed on a regular basis throughout the project life. The project team should be involved in this process so that they can develop and maintain a sense of ownership of, and responsibility for, the risks and associated risk response actions (Mojtahedi et al, 2010). Therefore, understanding the nature and type of risks that challenge projects is important for reaching informed decisions (Zou et al, 2007).

The existing body of literature lacks structured methods for collaborative risk identification and assessment. This paper focuses on collaborative risk identification because collaboration can help to increase the transparency within the construction networks, to reduce the vulnerability of the supply chain, and to improve the efficiency of risk management. Risk identification is a very vital step in the development of framework for collaborative management of risk in the construction projects.

\subsection{LITERATURE REVIEW}

Risk identification is the first step of risk management process, in which potential risks, risk sources associated with a construction projects are identified and examined (Akinci and 
Fischer, 1998; Mo Nui Ng, 2006). Several researchers have conducted studies to identify and categorize construction risk factors (Ashley et al. 1987, Al-Bahar and Crandall 1990, Kangari 1995, Smith and Bohn 1999). Uher (1994) identified 34 individual risks and categorized them in a single model, referring to some as activity risks that may affect individual activities, while others were global risks that were common to all activities. Azhar et al. (2008) identified 42 cost overrun factors and arranged them into three categories: macroeconomic factors, management factors, business and regulatory environment. Abd El-Razek et al. (2008) proposed 32 causes of delays of construction project in Egypt and found that the most important causes of delay are financing by contractor during construction, delays in contractor's payment by owner, design changes by owner or his agent during construction, partial payments during construction, and nonutilization of professional construction/contractual management. Enhassi et al. (2009) suggested 110 delay factors/causes, which were classified into 12 groups, resulting into time overruns and cost overruns in construction projects in the Gaza Strip.

Assaf and AlHejji (2006) conducted a time performance survey of different types of construction projects in Saudi Arabia to determine the causes of delay and their importance according to each project participant (owner, consultant, and contractor). They identified seventy three (73) causes of delay in their research. Aibinu and Odeyinka (2006) identified 44 delay factors related with the client, quantity surveyor, architect, structural engineer, services engineer, contractor, subcontractor, supplier and external factors. Perry and Hayes (1985) identified 29 primary sources of risks in a construction project associated with 9 risk groups: physical, environmental, design, logistics, financial, legal, political, construction and operation. Chan and Kumaraswamy (1996) identified 83 factors that may cause time delays in Hong Kong construction projects and classified them into eight categories; projectrelated, client-related, design team-related, contractor-related, materials, labor, plant and equipment and external factors. Long et al. (2004) presented 62 risk factors in large construction projects in Vietnam related with the financier, owner, contractor, consultant, project attributes, coordination and environment problems.

Sambasvian and Soon (2007) identified the delay factors and their impact on project completion in the Malaysian construction industry. The results indicated that the ten from a list of 28 different causes of delay were: (1) contractor's improper planning, (2) contractor's poor site management, (3) inadequate contractor experience, (4) client's inadequate financial resources and payments for completed work, (5) problems with subcontractors, (6) shortage in material, (7) labour supply, (8) equipment availability and failure, (9) lack of communication between parties, and (10) mistakes during the construction stage. Mustafa and Al-Bahar (1991) identified 32 risks in construction projects and classified them into six groups: acts of god, physical, financial and economical, design and job site-related risks. Based on the literature reviewed above and Tanzanian construction context, a total of fifty eight [56] risk factors are commonly identified to influence project performance, these are presented in Table 1 below.
Table 1 Risk factors identified as significant to influence project performance

\begin{tabular}{|c|c|c|c|}
\hline & Planning risk factors & & Design risk Factors \\
\hline 1 & $\begin{array}{l}\text { Inadequate project } \\
\text { planning }\end{array}$ & 1 & Changes in scope of work/client \\
\hline 2 & $\begin{array}{l}\text { Inefficient delivery } \\
\text { method }\end{array}$ & 2 & Inadequate survey data \\
\hline 3 & $\begin{array}{l}\text { Inappropriate contract } \\
\text { awards }\end{array}$ & 3 & Lack of experience of design team \\
\hline 4 & $\begin{array}{l}\text { Poor contractor and } \\
\text { supplier selection }\end{array}$ & 4 & $\begin{array}{l}\text { Inaccurate quantity estimates by the } \\
\text { design team }\end{array}$ \\
\hline 5 & Inappropriate pricing & 5 & Unclear scope of work \\
\hline 6 & $\begin{array}{l}\text { Delay in Land } \\
\text { acquisition (compassion) }\end{array}$ & 6 & $\begin{array}{l}\text { Inaccurate assumption on technical } \\
\text { data }\end{array}$ \\
\hline \multirow[t]{2}{*}{7} & $\begin{array}{l}\text { Length project } \\
\text { development period }\end{array}$ & 7 & Inadequate technical staffs \\
\hline & Construction risks & 8 & Design error and omission \\
\hline 1 & Differing site condition & & Financial risks \\
\hline 2 & $\begin{array}{l}\text { Inadequate site } \\
\text { investigation }\end{array}$ & 1 & Inadequate project funding \\
\hline 3 & Security problems & 2 & Currency inflation \\
\hline 4 & Unidentified utilities & 3 & Labour and material cost \\
\hline 5 & Congestion & 4 & Interest rate changes \\
\hline 6 & Theft at site & 5 & Bankruptcy of major participants \\
\hline 7 & $\begin{array}{l}\text { Unrealistic time } \\
\text { estimates by the } \\
\text { contractor }\end{array}$ & & Environmental risks \\
\hline 8 & $\begin{array}{l}\text { Low productivity of } \\
\text { personnel, equipment } \\
\text { and machines }\end{array}$ & 1 & Incomplete environmental analysis \\
\hline 9 & $\begin{array}{l}\text { Defective construction } \\
\text { materials }\end{array}$ & 2 & Historic/brownfield sites \\
\hline 10 & $\begin{array}{l}\text { Poor performance of } \\
\text { contractor }\end{array}$ & 3 & Disposal of construction waste \\
\hline \multirow[t]{2}{*}{11} & $\begin{array}{l}\text { Lack of project close } \\
\text { supervision by the client }\end{array}$ & 4 & Contaminated soils \\
\hline & Contractual risk factors & 5 & Effect on wetlands \\
\hline 1 & $\begin{array}{l}\text { Ambiguities in contract } \\
\text { formation }\end{array}$ & & Political Risk factors \\
\hline 2 & Bid chiseling & 1 & Political pressure/ interference \\
\hline 3 & $\begin{array}{l}\text { Project labour } \\
\text { agreements }\end{array}$ & 2 & $\begin{array}{l}\text { Change in law that adversely affect } \\
\text { the project }\end{array}$ \\
\hline \multirow[t]{2}{*}{4} & Claims and disputes & 3 & War, terrorism or hostilities \\
\hline & Force majeure & & Project management risks \\
\hline 1 & $\begin{array}{l}\text { Severe weather } \\
\text { condition }\end{array}$ & 1 & $\begin{array}{l}\text { Lack of } \\
\text { coordination/communication }\end{array}$ \\
\hline \multirow[t]{2}{*}{2} & Fire & 2 & Inefficient dispute resolution \\
\hline & Performance risks & 3 & Untimely inspection and testing \\
\hline 1 & $\begin{array}{l}\text { Not achieving required } \\
\text { quality }\end{array}$ & 4 & Delayed payments by the client \\
\hline \multirow[t]{2}{*}{2} & $\begin{array}{l}\text { Not meeting } \\
\text { stakeholders expectation }\end{array}$ & 5 & Inadequate inspection and testing \\
\hline & Safety Risks & 6 & Poor relationship between parties \\
\hline 1 & $\begin{array}{l}\text { Non availability/ no use } \\
\text { of safety equipment and } \\
\text { tools at site }\end{array}$ & & \\
\hline 2 & $\begin{array}{l}\text { Death/injuries at site due } \\
\text { to accidents }\end{array}$ & 3 & $\begin{array}{l}\text { Non availability of proper medical } \\
\text { facilities at site }\end{array}$ \\
\hline
\end{tabular}

This review has underscored that the risk factors that are responsible for poor performance of construction projects are many and vary from country to country and from one circumstance to another. It is against this background, the survey was designed to identify risk factors significantly affecting construction project which will in turn facilitate and enable project risks to be managed collaboratively throughout the project lifecycle. 


\subsection{RESEARCH METHODOLOGY}

The research methodology comprised a comprehensive literature review, a questionnaire survey and project file reviews. Three Government entities were involved in this study namely Tanzania National Roads Agency (TANROADS) which is responsible for construction and maintenance of roads in the country, Tanzania Building Agency (TBA) responsible for supervision and construction of public buildings and National Housing Corporation (NHC) a public corporation specializing in real estate business. The main reason for choosing these entities is because they undertake about sixty per cent $(60 \%)$ of the country's prominent construction activities in terms of both size and annual turnover. The projects they implement range from large and medium projects, construction and maintenance projects, and roads and buildings projects.

The questionnaire consisted of two sections. Section 1 solicited general information about the respondents (education qualification and experience of the respondent). Section 2 sought opinion of respondents on a total of 56 risk factors associated with construction projects. The respondents were requested, based on their experience and from a list of risk factors, to identify factors they perceive to have adverse affect on construction projects. Furthermore, respondents were also asked to evaluate the likelihood of occurrence of risk factors as well as to evaluate their impact on time, cost and quality objectives. Both the likelihood of occurrence and level of impact were to be rated on a Likert scale to facilitate data analysis in term of $3=$ 'High'; $2=$ 'Moderate' and $1=$ 'Low. Twenty questionnaires were personally administered to construction experts at the headquarters of each of the three entities in Dar es Salaam. In all three entities, respondents were selected among executive officers including project managers. In order to increase the coverage, additional twenty (20) questionnaire were administered at TANROADS regional managers' offices in Dar es salaam, Coast, Morogoro, Dodoma and Singida regions where each was served with four questionnaires to be responded by regional managers, heads of engineering, planning and procurement sections. Responses from questionnaires were complemented by follow-up interviews conducted to ensure the correctness of data and to clarify any doubts and misunderstandings.

In order to increase the reliability of the survey results, data were also collected from completed projects files implemented by the selected government entities. The primary objectives being to establish the risk factors commonly faced the projects, their sources, and consequences as documented by project implementers in these entities. For each project the following information were collected: project name, delivery methods, planned duration, final duration, and change on duration, planned budget, actual cost, and change in cost, percentage increase of duration and cost as well as risk factors assigned for these project performances.

\subsection{Method of data analysis}

The rating and ranking of significant risk factors was carried out based on their mean values. The survey responses were analysed using the multi-attribute method (Mbachu and Nkado, 2007). 'The mean (M) rating that represents the average of the responses for a particular risk factor was computed using the expression below.

$$
M=\left(\sum_{i=3}^{3} \mathrm{Wi}+\mathrm{fi}\right) \times \frac{100}{n} \%
$$

Where:

$M=$ mean representative rating assigned to a specific risk factor by all the respondents

$W_{i}=$ rating point, ranging from 1 to 3

$f_{i}=$ frequency of response associating a risk factor with a particular rating point.

$n=$ total number of respondents rating a particular risk factor in the survey.

\subsection{Level of significance of risk factor}

Based on the $\mathrm{M}$ values, the most significant risk factor is one with the highest $\mathrm{M}$ value. The risk factor having higher level of impact on project objectives is considered significant as shown in Equations 2 and 3.

$\begin{array}{ll}\text { Significant risk factor } & M>2.0 \\ \text { Non-significant risk factor } & M<2.0\end{array}$

Where: $1<\mathrm{M}<3$ on a 3-point Likert rating scale

\subsection{General Analysis of Respondents}

A total of 80 questionnaires were distributed out of which 61 were completed and returned equivalent to 76 per cent return rate. However, only 53 questionnaires were fully usable. The remaining 8 were partial, incomplete or incorrectly filled and therefore, excluded from the analysis. All 53 respondents had at least a Bachelor degree in Engineering, Architecture or Quantity surveying and had at least 5 years experience in construction. This kind of qualification and experience is considered adequate to enable respondents to give credible responses.

\subsection{RISKS FACTORS FROM THE QUESTIONNAIRE SURVEY}

As pointed out in the introduction part, the purpose of this survey was not only to generate a list of risks but also to identify the risks considered to significantly influences the delivery of construction projects. Table 2 to Table 4 indicates the rating of risk factors on the perceived influences on the project objectives (duration, cost, and quality). 
Table 2: Significant risk factors based on perceived influences on project duration

\begin{tabular}{|c|c|c|}
\hline & Duration & 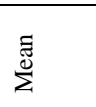 \\
\hline 1 & Inadequate projects funding & 3.00 \\
\hline 2 & Delay in land acquisition & 2.89 \\
\hline 3 & Inadequate project planning & 2.77 \\
\hline 4 & Inadequate technical staffs & 2.75 \\
\hline 5 & Low productivity of personnel, equipment and machines & 2.74 \\
\hline 6 & Unrealistic time estimates by the contractor & 2.73 \\
\hline 7 & Fire & 2.72 \\
\hline 8 & Inappropriate pricing & 2.70 \\
\hline 9 & Delayed payments by the client & 2.66 \\
\hline 10 & Inefficient dispute resolution & 2.64 \\
\hline 11 & Poor relationship between parties & 2.62 \\
\hline 12 & Changes in scope of work/client & 2.61 \\
\hline 13 & Inappropriate contract awards & 2.60 \\
\hline 14 & Poor performance of contractor & 2.55 \\
\hline 15 & Differing site condition & 2.53 \\
\hline 16 & Untimely inspection and testing & 2.49 \\
\hline 17 & Poor contractor and supplier selection & 2.49 \\
\hline 18 & Inadequate site investigation & 2.36 \\
\hline 19 & Inadequate survey data & 2.35 \\
\hline 20 & Theft at site & 2.34 \\
\hline 21 & Inaccurate quantity estimates by the design team & 2.32 \\
\hline 22 & Political pressure/ interference & 2.28 \\
\hline 23 & Unclear scope of work & 2.26 \\
\hline 24 & Inefficient dispute resolution & 2.21 \\
\hline 25 & Inefficient delivery method & 2.16 \\
\hline 26 & Bankruptcy of major participants & 2.15 \\
\hline
\end{tabular}

Table 3: Significant risk factors based on perceived influences on project cost

\begin{tabular}{|c|c|c|}
\hline & Cost & $\sum_{\Sigma}^{\tilde{\Xi}}$ \\
\hline 1 & Inadequate project planning & 2.89 \\
\hline 2 & Length project development period & 2.79 \\
\hline 3 & Inadequate projects funding & 2.70 \\
\hline 4 & Fire & 2.58 \\
\hline 5 & Inappropriate pricing & 2.55 \\
\hline 6 & Political pressure/ interference & 2.47 \\
\hline 7 & Changes in scope of work/client & 2.45 \\
\hline 8 & Differing site condition & 2.43 \\
\hline 9 & Labour and material cost & 2.42 \\
\hline 10 & Unclear scope of work & 2.41 \\
\hline 11 & Inadequate site investigation & 2.40 \\
\hline 12 & Inadequate survey data & 2.38 \\
\hline 13 & Inappropriate contract awards & 2.38 \\
\hline 14 & Inefficient delivery method & 2.37 \\
\hline 15 & Currency inflation & 2.36 \\
\hline 16 & Poor contractor and supplier selection & 2.36 \\
\hline 17 & Bid chiselling & 2.34 \\
\hline 18 & Poor performance of contractor & 2.28 \\
\hline 19 & Inadequate site investigation & 2.26 \\
\hline 20 & Defective construction materials & 2.23 \\
\hline 21 & Severe weather condition & 2.23 \\
\hline 22 & Delayed payments by the client & 2.23 \\
\hline 23 & Delay in Land acquisition (compassion & 2.17 \\
\hline 24 & Design error and omission & 2.16 \\
\hline 25 & Theft at site & 2.13 \\
\hline 26 & $\begin{array}{l}\text { Low productivity of personnel, equipment and } \\
\text { machines }\end{array}$ & 2.02 \\
\hline
\end{tabular}

Table 4: Significant risk factors based on perceived influences on project quality

\begin{tabular}{|l|l|c|}
\hline & \multicolumn{1}{|c|}{ Quality } & 疎 \\
\hline 1 & Inadequate project planning & 2.62 \\
\hline 2 & Lack of project close supervision by the client & 2.58 \\
\hline 3 & Poor performance of contractor & 2.55 \\
\hline 4 & Inaccurate assumption on technical & 2.54 \\
\hline 5 & Defective construction materials & 2.45 \\
\hline 6 & Inappropriate pricing & 2.44 \\
\hline 7 & Design error and omission & 2.43 \\
\hline 8 & Inadequate technical staffs & 2.41 \\
\hline 9 & Inadequate project funding & 2.37 \\
\hline 10 & Inadequate inspection and testing & 2.35 \\
\hline 11 & Inadequate survey data & 2.25 \\
\hline 12 & Unrealistic time estimates by the contractor & 2.20 \\
\hline 13 & Inefficient delivery method & 2.15 \\
\hline 14 & Inappropriate contract awards & 2.13 \\
\hline 15 & Poor contractor and supplier selection & 2.10 \\
\hline 16 & Fire & 2.05 \\
\hline 17 & Lack of experience of design team & 2.02 \\
\hline & & \\
\hline
\end{tabular}

\subsection{SUMMARY OF THE DETAILS OF PROJECTS}

In order to increase the reliability of the survey results, data were also collected from completed projects implemented by TANROADS, TBA, and NHC. The primary objectives being to establish the risk factors commonly encountered during the implementation of the projects and likewise to establish their sources and consequences as documented by project implementers in these entities.

\subsection{Tanzania Roads Agency (TANROADS)}

Project files of 24 road projects implemented by TANROADS between 2003- 2014 were reviewed during this data collection exercise. For each project the following information were collected: project name, delivery methods, planned duration, final duration, changes on duration, planned budget, actual cost, change in cost, and percentage in increase of duration, cost as well as risk factors assigned for these performance. It was noted that most road projects were mostly affected by a total of six risk factors, which are inadequate project preparation (project planning), delayed payment by the client (inadequate funding), delayed compensation of land and properties, delayed reallocation of utilities (telecommunication and power lines), delayed approvals for various substantial claims and poor performance of contractor.

\subsection{Tanzania Building Agency (TBA)}

Project files of 14 building projects implemented or supervised by TBA between 2003- 2014 were reviewed during this data collection exercise. Information of each project similar to those collected in TANROADS was gathered. From this review it was noted that most building projects were affected by two main risk factors, these are: inadequate project preparation (project planning) and delayed payment by the client (inadequate funding). 


\subsection{National Housing Cooperation (NHC)}

Project files of 11 building projects implemented or supervised by TBA between 2003- 2014 were reviewed during this data collection exercise. Information similar to those gathered in TANROADS and TBA were collected. From this review it was seen that most building projects were affected mainly by two risk factors, these are: inadequate project preparation (project planning) and poor performance of contractors.

Findings from these three entities indicate that, project planning is not properly taken into consideration throughout project life cycle in Tanzania. This indicates that planning risks can influence to a great extent the successful completion of construction projects. Good project planning practice requires project participants to carefully analyze all potential risks to the project, quantify them, develop a mitigation plan against them, and a contingency plan should any of them materialize. Based on the project files reviews about the practice of risk management in Tanzania, risk management is poorly applied in projects. Risk management planning is considered most important and significant step in risk management. This finding is supported by the study of Wang and Gibson (2008) and Dvir et al (2003) who argued that planning and analysis are very important processes in risk management implementation. However, there is no policy, procedure, specific department or people assigned to manage risk in all these three public entities. Experience is considered the important factor to face risks.

Another critical risk factor noticed in project files was the delayed payments from the clients. A project cannot proceed without adequate financing. It has been very common in Tanzanian construction industry especially infrastructures projects owned and financed by the government to commence without proper funding plans, as a result contractors and consultants only get paid when funds become available. Many construction projects had stopped if not progressing in low pace because of delayed payments or inadequate funding. Many projects accrued interest for non paid interim payment certificates hence increasing project cost. This finding is supported by the study of Adams (2008) who provides evidence within the Ghanaian context by stating that payment delays on the government stifles progress on projects.

When assessing the significance of any given risk, it is necessary to consider both probability of occurrences and impact of a given risk. Clearly an uncertain event which is likely to occur (i.e. it has high probability) but which would have little or no effect on objectives (low impact) is not significant. Similarly a risk may have such a low probability that it might not be worth considering even if some significant impact were theoretically possible. Chapman (2001) accepted risk as the "likelihood of occurrence and the degree of impact of a negative event adversely affecting an activity". Table 5 lists the 24 identified critical risk factors as perceived by the respondents and findings from project files to have major overall impacts on issues related to project performance and delivery such as cost, time and quality.
Table 5: Risk factors perceived to have influences on overall project objectives

\begin{tabular}{|c|c|c|c|}
\hline $\mathrm{S} / \mathrm{N}$ & Risk Factors & Mean & Std deviation \\
\hline 1 & Inadequate project planning & 2.81 & 0.505 \\
\hline 2 & Inadequate projects funding & 2.64 & 0.740 \\
\hline 3 & $\begin{array}{l}\text { Inappropriate pricing by the } \\
\text { contractor }\end{array}$ & 2.62 & 0.540 \\
\hline 4 & $\begin{array}{l}\text { Lack of project close supervision by } \\
\text { the client }\end{array}$ & 2.57 & 0.800 \\
\hline 5 & $\begin{array}{l}\text { Low productivity of personnel, } \\
\text { equipment and machines }\end{array}$ & 2.51 & 0.655 \\
\hline 6 & Delayed payments by the client & 2.50 & 0.649 \\
\hline 7 & Poor performance of contractor & 2.49 & 0.722 \\
\hline 8 & $\begin{array}{l}\text { Delay in land acquisition } \\
\text { (Compassions) }\end{array}$ & 2.47 & 0.320 \\
\hline 9 & Ineffective project delivery system & 2.46 & 0.716 \\
\hline 10 & Untimely inspection and testing & 2.45 & 0.690 \\
\hline 11 & Design error and omission & 2.44 & 0.590 \\
\hline 12 & Defective construction materials & 2.42 & 0.673 \\
\hline 13 & Incomplete/ inadequate survey data & 2.41 & 0.811 \\
\hline 14 & Political pressure/ interference & 2.40 & 0.907 \\
\hline 15 & Length project development period & 2.34 & 0.787 \\
\hline 16 & Change in scope of works & 2.30 & 0.811 \\
\hline 17 & Poor relationship between parties & 2.30 & 0.632 \\
\hline 18 & Labour and material cost escalation & 2.26 & 0.819 \\
\hline 19 & Claims and disputes & 2.21 & 0.927 \\
\hline 20 & Inadequate site investigation & 2.19 & 0.811 \\
\hline 21 & $\begin{array}{l}\text { Unrealistic time estimates by the } \\
\text { contractor }\end{array}$ & 2.17 & 0.593 \\
\hline 22 & Differing site conditions & 2.15 & 0.775 \\
\hline 23 & Unclear scope of work & 2.08 & 0.858 \\
\hline 24 & Inadequate technical staffs & 2.00 & 0.434 \\
\hline
\end{tabular}

\subsection{CONCLUSION}

This paper presented the findings of the identification of critical risk factors causing the poor performance in construction projects as perceived by TANROADS, TBA and NHC and findings from project files. These risk factors include inadequate project planning, inadequate projects funding, inappropriate pricing by the contractor and lack of project close supervision by the client. Other includes low productivity of personnel, equipment and machines, delayed payments by the clients, poor performance of contractors and delay in land acquisition (compassion). Other critical risk factors are ineffective project delivery system, untimely inspection and testing, design error and omission, defective construction materials, incomplete/inadequate survey data, political interference, length project development period and change in scope of works. Other includes poor relationship between parties, labour and material cost escalation, claims and disputes, inadequate site investigation, unrealistic time estimates, differing site conditions, unclear scope of work and inadequate technical staffs

\subsection{RECOMMENDATION}

To minimize project failure due to risks, project teams should collaboratively identify and manage project risks. On the issue of delayed payments, clients generally have to make sure that; they have to mobilize adequate funds before a project begins to smooth implementation of the project. Clients and consultants should also perform timely inspection and testing for the completed works and issue payments certificates and make payments on time to facilitate progress the works. 


\section{REFERENCES}

[1] Abd El-Razek M., E, Bassioni, H.A and Mobarak A. M. "Causes of delay in building construction project in Egypt," Journal of Construction Engineering and Management, Vol.134 No11, pp. 831-841, 2008

[2] Adams, F.K. "Risk perception and Bayesian analysis of international construction contract risks: the case of payment delays in a developing economy", International Journal of Project Management, Vol. 26, pp. 138-48. 2008, Available from: https://www.researchgate.net/publication/262262757 [accessed Dec 16 2017]

[3] Ahmed, A., Kayis, B., Amornsawadwatana, S., (2007), "A review of technicians for risk management in projects", Benchmarking International Journal, Vol. 14 No. 1, pp. 22-36

[4] Aibinu A. and Odeyinka H. A. "Construction delays and their causative factors in Nigeria," Journal of Construction Engineering and Management, Vol.132, No.7, pp. 667-677, 2006

[5] Akınc1, B. and Fischer, M. "Factors affecting contractors' risk of cost overburden," Journal of Management in Engineering, Vol.14, No. 1, pp. 67-76, 1998.

[6] Al-Bahar, J., Crandall, K.C. "Systematic risk management approach for construction projects", Journal of Construction Engineering and Management, Vol. 116, pp. 533-546, 1990.

[7] Ashley, D.B. and Bonner, J. J. "Political risks in international construction", Journal of Construction Engineering and Management, Vol. 113, No. 3, pp. 447-467, 1987.

[8] Assaf S. A. and Al-Hejji S. "Causes of delay in large construction projects," International Journal of Project Management, Vol. 24, pp. 349-357, 2006.

[9] Azhar N., Farooqui R.U. and Ahmed S. M. "Cost overrun factors in construction industry of Pakistan," First International Conference on Construction in Developing Countries, 2008, Karachi, Pakistan

[10] Baloi, D and Price A. D. F. "Modeling global risk factors affecting construction cost performance", International Journal of project management, Vol.21, No. 4, pp. 261-269, 2003.

[11] Chan D.W.M. and Kumaraswamy M. "A comparative study of causes of time overruns in Hong Kong construction projects", International Journal of Project Management, Vol. 15 No.1, pp. $55-63,1996$.

[12] Chapman R. J. "The Controlling Influences on Effective Risk Identification and Assessment for Construction Design Management," International Journal of Project Management, Vol.19, pp. 147-160, 2001

[13] Dvir, D., Tsvi Raz, \& Shenhar, A. "An empirical analysis of the relationship between project planning and project success, International Journal of Project Management, pp. 89-95, 2003.

[14] Enshassi A., Al-Najjar J. and Kumaraswamy M. "Delays and cost overruns in the construction projects in the Gaza Strip," Journal of Financial Management of Property and Construction, Vol.14 No. 2, pp. 126-151, 2009

[15] Kangari, R. "Risk management perceptions and trends of U.S construction", Journal of Construction Engineering and Management, Vol. 121, No. 4, pp. 422-429, 1995.
[16] Long N. D., Ogunlana S., Quang T. and Lam K. C. "Large construction projects in developing countries" a case study from Vietnam," International Journal of Project Management, Vol.22 No.7, pp. 553-561, 2004

[17] Hillson, D. Dealing with business uncertainty, Unloaded from: http://www.risk-doctor.com/briefings. 2011. (Accessed on $14^{\text {th }}$, June, 2016)

[18] Mbachu, J. and Nkado, R. "Factors constraining successful building implementation in South Africa," Construction Management and Economics, Vol, 25, No.1, pp. 39-54, 2007.

[19] Mojtahedi, S.M.H., Mousavi, S.M., Makui, A. "Project risk identification and assessment simultaneously using multi attribute group decision making technique", Safety Science, Vol.48, pp. 499-507, 2010.

[20] Mo Nui Ng, H.S., "Dynamic decision support for contingency management and allocation for construction projects", Doctoral Dissertation, University of Illinois, Urbana Champaign, 2006

[21] Msita, K. M and Mamiro, J. "Rising road construction costs in Tanzania", A legitimate concern?; Paper presented to regional conference on innovations in road financing and management, $26^{\text {th }}$ to 27th August, 2010, Arusha, Tanzania

[22] Mustafa M.A. and Al-Bahar J.F. "Project risk assessment using the analytic hierarchy process," IEEE Transactions on Engineering Management, Vol.38 No.1: pp46-52, 1991.

[23] Perry J. G. and Hayes R.W.,"Risk and its management in construction projects", Proceedings of the Institution of Civil Engineers, Vol.78, No. 3, pp. 499-521, 1985.

[24] Public Procurement Regulatory Authority (PPRA), Technical and procurement audit reports for construction projects in Government entities in Tanzania, 2011.

[25] Road Fund Board (RFB), Technical and procurement audit reports for construction projects in Government entities in Tanzania, 2009

[26] Sambasivan, M. and Soon, Y.W., (2007), "Causes and effects of delays in Malaysian construction industry", International Journal of Project Management, Vol. 25, No. 5, pp. 517-526

[27] Smith, G. R. and Bohn, C.M. "Small to medium contractor contingency and assumption of risk", Journal of Construction and Engineering Management, Vol.125, No. 2, pp. 101-108, 1999.

[28] Uher, T. "A general risk classification model for construction," Australian Institute of Building Papers, Vol. 5, pp. 25-33, 1994.

[29] Wang, S., Dulaimi, M. and Aguria, Y. "Risk management framework for construction projects in developing countries." Construction Management and Economics, Vol. 22. No.3, pp.237-252, 2004

[30] Wang, Y.-R., and Gibson, G. E. "A study of pre-project planning and project success using regression models", in The 25th International Symposium on Automation and Robotics in Construction, ISARC-2008 pp. 688-696, 2008

[31] $\mathrm{Yu}, \mathrm{Z}$. "Integrated risk management under deregulation. Power Engineering Society" Summer Meeting, IEEE, Vol.3, pp.1251$1255,2002$.

[32] Zou, P. X.W., Zhang, G. and Wang, J,"Understanding the key risks in construction projects in China" International Journal of project management Vol.25, No. 6, pp.601-614, 2007. 